\title{
The Influence of Gold Food Indonesia Meat Shop's Service Quality on Customer Satisfactions and Customer Loyalty during the Pandemic of Covid-19
}

\author{
Bagus Prayogo $^{1}$, Budi Guntoro ${ }^{1, *}$ and MAU Muzayyanah ${ }^{1}$ \\ ${ }^{1}$ Faculty of Animal Science, Universitas Gadjah Mada, Jl Fauna 3 Bulaksumur, Yogyakarta, Indonesia) \\ *Corresponding author. Email: budiguntoro@ugm.ac.id
}

\begin{abstract}
The purpose of this study was to investigate the effect of service quality on satisfaction and loyalty of costomuer at Gold Food's Meat Shop during the pandemic of corona virus-19 (COVID 19) located in West Imogiri Street, Bantul, Yogyakarta. Total of 70 respondents, who bought meat at Gold Food's Meat Shop for twice in a month, were observed in this study. A non-probability sampling technique with method of purposive sampling were applied in this study. The analysis that used in this study consisted of validity and reliability tests, simple linear regression, and testing a hypothesis, which used the t-test and considered the determination coefficent $\left(R^{2}\right)$. A significant positive effects $(\mathrm{P} \leq 0.05)$ had been shown by service quality on consumer satisfaction using simple linear regression with $\mathrm{R}^{2}=0.192$. It meaned that total of $19.2 \%$ of the customer satisfaction variable was affected by the service quality. On the other hand, total of $80.8 \%$ of custumer statisfaction could be affected by other variables, which was not applied by this research model. Moreover, the significant effect $(\mathrm{P} \leq 0.05)$ was also shown on customer loyalty by customer satisfaction variables, with $R^{2}=0.305$. It indicated that the effect of customer satisfaction affected $30.5 \%$ on customer loyalty, while antoher $69.5 \%$ of customer loyalty could be influenced by other variables, which was not applied by this research model.
\end{abstract}

Keywords: Customer loyalty, pandemic Covid-19, customer satisfaction, service quality.

\section{INTRODUCTION}

Corona Virus Disease 2019 (COVID-19) gave an impact on various sectors in Indonesia, including the food sector related to livestock business activities, one of them is the sale of beef by meat traders in traditional markets. Human interactions such as face to face meeting are also limited, because it is feared that it will cause the spread of COVID-19 to be wider, one of which is the limitation of market operating hours and the application of health protocols when entering the market area. This makes some meat traders in traditional markets experience a decrease in operating income. During the implementation of the new life adaption (new normal) COVID-19 meat shop business actors to maintain customer buying interest, so that customers still feel safe and comfortable to keep buying in traditional market namely by improving the quality of service.
Kotler [1] stated that the quality of service affected customer satisfaction massively. According to Sukmawati et al. [2] the varibel of service quality had the strongest direct influence on customer loyalty. Customer satisfaction can be defined as a feeling of customer of pleasure or disappointment, which appear after comparing the perception of a store's performance with all of their expectations. High satisfaction would create customer loyalty [1]. Aydin et.al. [3] stated that customer loyalty is a customer's commitment to repurchase and subscribe to a store. Griffin [4] stated that customer loyalty is very useful for maintaining relationship between stores and customers. Research on customer loyalty that has been done before, emphasizes efforts to analyze the factors that influence customer satisfaction. Previous study [5] reported that an increased customer satisfaction with the company, the level of loyalty would also increase. Meanwhile customer satisfaction did not always have a relationship with customer loyalty [6]. Therefore, this study examined how the quality of service of Gold Food Indonesia's meat shop as a provider of beef and chicken products influences the service quality and 
customer loyalty during the current Pandemic of COVID19. This study aimed to analyze the effect of service quality on customer satisfaction and analyze the effect of customer satisfaction on customer loyalty.

\section{MATERIALS AND METHODS}

This research was conducted in Yogyakarta and data collection was carried out by using a structured questionnaire. The research data collection was carried out in May 2021. The questionnaire used in this study contains structured questions and alternative answers were already available. The questionnaire consisted of the respondent's profile (demographic data), questions about service quality (physical evidence, reliability, responsiveness, assurance, empathy), questions about satisfaction, questions about customer loyalty. The scale used in this questionnaire was a Likert scale with the provisions of 1 being strongly disagree and 5 being strongly agree. The sampling method used in this research was purposive sampling. The respondents needed to fill out the research questionnaire are people in Yogyakarta who have bought a Gold Food Indonesia. The respondent's criteria used are that they have ever bought meat products in Gold Food Indonesia at least two times. The total of samples needed was 70 respondents. Samples have taken as many as 70 respondents. According to Silalahi [7] the total of samples taken about

Table 1. Respondents' assessment of the variables of service quality, satisfaction, and customer loyalty at the meat shop Gold Food $(\mathrm{n}=70)$

\begin{tabular}{|c|c|c|c|c|c|c|}
\hline \multirow{2}{*}{ Indicator } & \multicolumn{5}{|c|}{ Total of Respondents } & \multirow{2}{*}{ Average } \\
\hline & SDA & DA & $\mathrm{N}$ & A & SA & \\
\hline \multicolumn{7}{|l|}{ 1. Service Quality Variable } \\
\hline \multicolumn{7}{|l|}{ a. Physical Evidence Attribute } \\
\hline $\begin{array}{l}\text { The location of Gold Food meat shop is strategic and } \\
\text { easy to reach }\end{array}$ & 0 & 0 & 3 & 27 & 40 & 4.53 \\
\hline $\begin{array}{l}\text { The arrangement of the display of meat products at the } \\
\text { Gold Food meat shop is attractive }\end{array}$ & 0 & 0 & 1 & 16 & 53 & 4.74 \\
\hline $\begin{array}{l}\text { Completeness of adeguate facilities (grinding machine, } \\
\text { chopping machine, freezer, scales, waiting chair, etc) }\end{array}$ & 0 & 0 & 13 & 28 & 29 & 4.23 \\
\hline The cleanliness of the store is always in good condition & 0 & 0 & 6 & 21 & 43 & 4.53 \\
\hline Index Value & \multicolumn{6}{|c|}{4.5} \\
\hline \multicolumn{7}{|l|}{ b. Reliability Attribute } \\
\hline The employees serve customers professionally & 0 & 0 & 4 & 28 & 38 & 4.5 \\
\hline The accuracy in calculating notes and refunds & 0 & 0 & 3 & 26 & 41 & 4.54 \\
\hline $\begin{array}{l}\text { The employees speak in a friendly and politely in all } \\
\text { situations }\end{array}$ & 0 & 0 & 3 & 23 & 44 & 4.6 \\
\hline $\begin{array}{l}\text { The employees are able to serve customers quickly and } \\
\text { precisely }\end{array}$ & 0 & 1 & 1 & 25 & 43 & 4.57 \\
\hline Index Value & \multicolumn{6}{|c|}{4.55} \\
\hline \multicolumn{7}{|l|}{ c. Responsiveness Attribute } \\
\hline $\begin{array}{l}\text { The employees are willing to help customers' problems } \\
\text { quickly }\end{array}$ & 0 & 0 & 5 & 26 & 39 & 4.5 \\
\hline $\begin{array}{l}\text { The employees must be able to overcome customer } \\
\text { complaints well }\end{array}$ & 0 & 1 & 2 & 29 & 38 & 4.5 \\
\hline $\begin{array}{l}\text { The willingness of employees to respond to customers in } \\
\text { all situation }\end{array}$ & 0 & 1 & 2 & 28 & 39 & 4.5 \\
\hline $\begin{array}{l}\text { The employees provide information in a clear and easy } \\
\text { to understand }\end{array}$ & 0 & 1 & 3 & 31 & 35 & 4.43 \\
\hline Index Value & \multicolumn{6}{|c|}{4.48} \\
\hline
\end{tabular}

SDA: strongly disagree; DA; disagree; N: netral; A: agree; SA: strongly agree) Continued $\rightarrow$ 


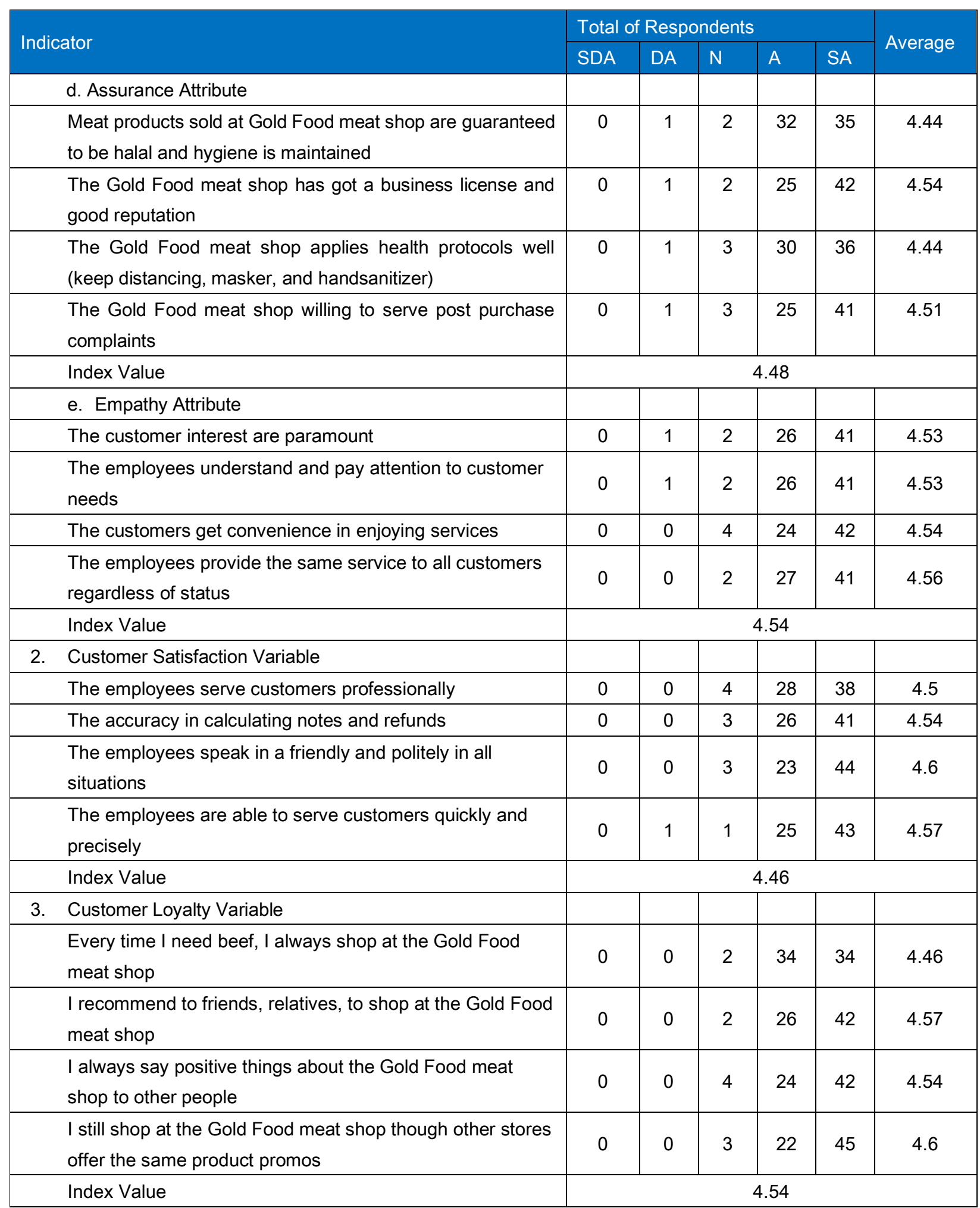

SDA: strongly disagree; DA; disagree; N: netral; A: agree; SA: strongly agree)

30 and can be done statistical analysis. Researchers added 40 samples to 70 so that the research data obtained is more accurate.

The data used in this research were primary data. Cooper dan Schindler [8] said, primary data were the original work of a research or raw data without interpretation. The time data collection was carried out in May 2021. Questionnaire were distributed directly and filled in directly by customers of Gold Food. The research used in this study was a simple linear regression, to find out the effect of service quality on customer satisfaction and satisfaction on customer loyalty. 
Table 2. The effect of service quality on customer satisfaction Gold Food meat shop

\begin{tabular}{|l|l|l|l|l|}
\hline Variable & $\mathrm{B}$ & & Significance & Conclusion \\
\hline Constant & 10.478 & & .000 & \\
\hline Service Quality & .087 & & .000 & $\mathrm{H} 1$ accepted \\
\hline $\mathrm{R}$ & R Square & \multicolumn{2}{|l|}{ Adjusted $R$ Square } & \multicolumn{2}{l|}{ Std. Error of the Estimate } \\
\hline .438 & .192 & .180 & 1.24430 & \\
\hline
\end{tabular}

Remark: $*=$ Significant $(\mathrm{p} \leq 0.05)$

Table 3. The effect of Customer Satisfaction on customer loyalty of Gold Food meat shop

\begin{tabular}{|c|c|c|c|c|}
\hline \multicolumn{2}{|l|}{ Variable } & $\mathrm{B}$ & Significance & Conclusion \\
\hline \multicolumn{2}{|l|}{ Constant } & 10.478 & .000 & \\
\hline \multicolumn{2}{|l|}{ Constant } & 5.410 & .024 & \\
\hline \multicolumn{3}{|c|}{ Customer Satisfaction } & .695 & \\
\hline \multicolumn{3}{|c|}{ F count 29.899} & Significance & \\
\hline $\mathrm{R}$ & R Square & Adjusted R Square & \multicolumn{2}{|c|}{ Std. Error of the Estimate } \\
\hline .553 & .305 & .295 & 1.45039 & \\
\hline
\end{tabular}

Remark: *= Significant $(\mathrm{p} \leq 0.05)$

\section{RESULT AND DISCUSSION}

Respondents' responses to the indicators in this study were calculated for the average score for the variables of service quality, satisfaction and customer loyalty of the meat shop of Gold Food. The attributes of service quality at the Gold Food meat shop in this study consist of physical evidence, reliability, responsiveness, assurance, and empathy, detailed customer satisfaction and loyalty can be seen in Table 1 . The results of the study obtained characteristic, namely $55.71 \%$ of respondents in this study and the majority were male. The majority of respondents were aged 22-34 years old that was $78.57 \%$. Respondents' age data shows that the majority of Gold Food's meat shop customers are adults. The profession of the majority of respondents are private employees and students by $30 \%$, the intensity of purchasing of respondents in this study is the majority 2 times a month with a percentage of $37.14 \%$ and Gold Food meat shop customers mostly know Gold Food meat shop through advertisement which is $41.43 \%$

Based on the results of the study, obtained the level of service quality which consists of five attributes, namely physical evidence, reliability, responsiveness, assurance and empathy all show a high value index (Table 1). The level of customer satisfaction has an index value of 18.38 which is in the high category and the level of customer loyalty has an index value of 18.17 which is in the high category. Based on the results of simple linear regression analysis, the service quality variable presented a significant positive effect $(\mathrm{P} \leq 0.05)$ on the customer satisfaction of the Gold Food meat shop with $\mathrm{R}^{2}=0.192$ (Table 2). It indicated that total of $19.2 \%$ of customer satisfaction variable was affected by the service quality variable. On the other side, total of $80.8 \%$ of consumer satisfaction was influenced by other variables, which were not applied in this research model. In addition, the variable of customer satisfaction showed a significant positive effect $(\mathrm{P} \leq 0.05)$ on customer loyalty of Gold Food meat shop, with $\mathrm{R}^{2}=0.305$ (Table 3 ). It indicated that the effect of customer satisfaction affected $30.5 \%$ on customer loyalty. While, antoher $69.5 \%$ of customer loyalty could be influenced by other variables, which was not applied by this research model.

\section{CONCLUSION}

Service quality has a positive and significant effect on customer satisfaction at the Gold Food meat shop. This means that if the quality of service improved, the customer satisfaction of the Gold Food meat shop will also increase. Customer satisfaction has a positive and significant effect on customer loyalty at the Gold Food meat shop. This means that if customer satisfaction increases, the loyalty of the Gold Food meat shop customer will also increase.

\section{REFERENCES}

[1] Kotler, P. 2000. Manajemen Pemasaran. Edisi Mileinium. Jakarta: PT. Indeks Kelompok Gramedia.

[2] Sukmawati, I dan James D. D. Massie. 2012. Pengaruh Kualitas Pelanggan Dan Kepercayaan Pelanggan Terhadap Loyalitas Pelanggan pada PT 
Air Manado. Skripsi. Fakultas Ekonomi dan Bisnis. Universitas Sam Ratulangi. Manado.

[3] Aydin, S. dan G. Ozer dan O. Arasil, 2005. Customer Loyalty and the Effect of Switching Costs as a Moderator Variable: A Case in The Turkish Mobile Phone Market. Marketing Intelligence and Planning. 23/1. 89-104.

[4] Griffin, J. 2005. Customer Loyalty: Menumbuhkan dan Mempertahankan Kesetiaan Pelanggan. Erlangga. Jakarta.

[5] Bolton, R. N., Kannan, and Bramlett. 2000. Implications of Loyalty Program Membership and Services Experiences for Customer Retention and Value. Journal of the Academy of Marketing Science. Volume 28, No. 1, pages 95-108. New York.

[6] Fornell, J. E and Wernerfelt. 2002. Customer Relations \& Repport: Professional Development Series. South Western Thomson Learning. Australia.

[7] Silalahi, U. 2006. Metode Penelitian Sosial. Bandung: Unpar Press.

[8] Cooper, D.R. and P.S. Schindler. 2014. Business Research Methods. 12th ed. New York: McGrawHill. 